\title{
Overcoming challenges to discover drugs for liver stages of Plasmodium vivax
}

\author{
Dennis E Kyle \\ From Challanges in malaria research: Core science and innovation \\ Oxford, UK. 22-24 September 2014
}

Perhaps the most daunting challenge for eliminating malaria is developing novel interventions to eradicate the dormant hypnozoite of Plasmodium vivax. New in vitro models are urgently needed to accelerate drug and vaccine discovery for liver stages of $P$. vivax malaria, yet maintaining the physiology of primary hepatocytes in long-term culture in vitro remains a major obstacle. Several advanced liver models support hepatic phenotypes necessary for drug and disease studies, yet these models are characterized by intricate features such as co-culture with one of more supporting cell types or advanced media perfusion systems. Regardless of the culture system, primary hepatocyte culture systems suffer from reproducibility issues due to phenotypic variation and expensive, limited supplies of donor lots. We have developed a microfluidic bilayer device that sustains primary human hepatocyte phenotypes, including albumin production, factor IX production, cytochrome P450 3A4 drug metabolism and bile canaliculi formation for weeks in a simple monoculture format with static media. Using a variety of channel architectures, we discovered how primary cell phenotype is promoted by spatial confinement within the microfluidic channel, without the need for perfusion or co-culture. This new model is amenable to 384 well screening platforms and utilizes a few hundred primary human hepatocytes, maintains hepatocyte function for weeks in vitro within a relatively simple model, and addresses many of the major hurdles in human hepatocyte culture research.

Published: 22 September 2014

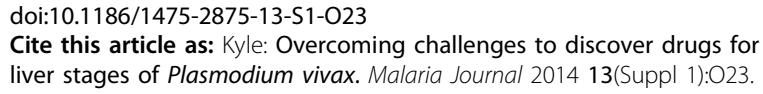

Cite this article as: Kyle: Overcoming challenges to discover drugs for liver stages of Plasmodium vivax. Malaria Journal 2014 13(Suppl 1):O23.

Department of Global Health, College of Public Health, University of South Florida, USA

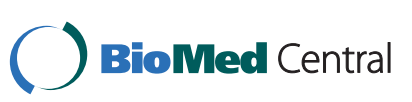

(c) 2014 Kyle; licensee BioMed Central Ltd. This is an Open Access article distributed under the terms of the Creative Commons Attribution License (http://creativecommons.org/licenses/by/4.0), which permits unrestricted use, distribution, and reproduction in any medium, provided the original work is properly cited. The Creative Commons Public Domain Dedication waiver (http:// creativecommons.org/publicdomain/zero/1.0/) applies to the data made available in this article, unless otherwise stated.
Submit your next manuscript to BioMed Central and take full advantage of:

- Convenient online submission

- Thorough peer review

- No space constraints or color figure charges

- Immediate publication on acceptance

- Inclusion in PubMed, CAS, Scopus and Google Scholar

- Research which is freely available for redistribution 